\title{
A SHORT HISTORY OF SEMINARS ON "RECENT RESEARCH AND DESIGN PROGRESS IN AERONAUTICAL ENGINEERING AND ITS INFLUENCE ON EDUCATION"
}

The aeronautical sciences and aerospace industry are by nature international. Coming from this thesis, we decided in 1994 to organise an international meeting, further called the Seminar, devoted to "RECENT RESEARCH AND DESIGN PROGRESS IN AERONAUTICAL ENGINEERING AND ITS INFLUENCE ON EDUCATION”. The objective of that first Seminar and following ones was to organise a multinational forum for discussion and interchange of aeronautical issues and subjects, focusing on their influence on university education. Other goals included promoting international co-operation in the study of the problems in aeronautical science and technology in which there was a common interest and facilitating personal contacts between scientists, university lecturers, and industrial engineers. Our area of interest was aeronautical technology, as it is widely understood. The special focus of our Seminars was concentrated on Aircraft Design, Aircraft Oriented Aerodynamics, Flight Dynamics, Helicopter Dynamics, Computational Fluid Dynamics, Materials and Structures, Control and Flight Tests. All these topics and their influence on the teaching process at a technical university were considered - what we believe is a specific feature of our Seminars. We notice a mutual influence between contemporary research and education; it is impossible to deliver a modern university lecture without conducting one's own serious research or design, and it is almost impossible to become a serious, successful researcher or designer without being a graduate of a good, contemporary university. The other specific feature of our Seminars is a student session. An international jury of professors and deans from aerospace faculties all over the world observes the sessions and awarded the best student papers diplomas (sometimes with small prizes contributed by different institutions). We believe that the student sessions promote personal contacts between students and foreign lecturers and encourage students to work harder in the future. For all of us, it is the promise of a new generation of engineers, designers and scientists.

We are aware that various, sometimes very prestigious, international conferences in the field of aeronautics are organised all over the world. Some of them are quite specialised and gather many outstanding, internationally recognised experts. Our intention is instead to invite a few outstanding specialists from a selected field of aeronautics and discuss only selected topics. The advantage of such an approach is that many scientists and young engineers from Poland and other central and eastern European countries are able to take part in this event because costs are lower than those held in Western countries.

At the last Seminar in Tallinn, there were participants from 13 countries: Estonia, Sweden, Russia, Latvia, the U.S.A., the United Kingdom, Italy, Poland, Lithuania, Germany, the Czech Republic, Ukraine, and Japan. Among them were lecturers from 18 universities, including universities in Maryland, Cranfield, Brno, Linkoping, Lund, Moscow (2), Nagoya, Kiev, Torino, Rzeszow, Tartu, Stuttgart, Riga (2), Manchester, Warsaw and Vilnius. Alenia Aeronautica, the research institutes attached to the Warsaw Institute of Aviation, Airlines Lufthansa Technical Training, and Finn air represented European industry. Professors from Cranfield University and from Brno University delivered distinguished, invited lectures. The Seminar in Tallinn was the third one organized in the Baltic countries, after earlier Seminars in Vilnius and Riga. There was never a big aerospace industry in the Baltic countries, and there is probably no chance for a large-scale industry in the future. However, these countries have technical universities, SMEs, and have brilliant, welleducated people. They can participate in the European research market and in this way make an essential contribution to the growth of the gross national product. We know that technology and research developed in aerospace influence the entire national economy and create jobs and that technological results are often used in other sectors of the national economy. From an organizational point of view, the last seminar in Tallinn was a great success for the local organizers from Tartu Aviation College coordinated by prof. Villu Mikita. All members of the Seminar Organizing and Scientific Committee appreciate the effort of prof Villu Mikita very much and express on behalf of the all seminar participants their deep gratitude. At the opening ceremony, prof. Ene Ergma - vice president of the Estonian parliament — passed on greetings to our participants, and at the closing ceremony Mrs M. Reps - Estonian minister of transportation — was present and expressed her warmest greetings to seminar participants and wished all the best for future seminars.

Our meetings are a natural forum where we can look for partners for joint projects, research grants, and various scientific activities on an international basis. The first Seminar organised in 1994 was held 10 years before 2004, the year our countries (Poland, Czech Republic, Lithuania, Latvia, and Estonia) joined the European Union. However, then and now, the European Union, through the commissions in Brussels, encourage scientists to organise international teams and to apply for European funding. One of the many examples coming soon is the Seventh Framework 
Programme. Its philosophy is very simple - mutual relations create additional value and a kind of synergy and can accelerate overall progress in aeronautics. Many times we have asked participants of Seminars to not miss the occasion and establish new friendships and partnerships for future activity. It is no accident that many teams from Warsaw, Brno, Vilnius and Riga were very successful in the Fifth and Sixth Framework Programmes. We also gain experience and established good foreign relations at our Seminars. This is true of colleagues in the central and eastern parts of Europe and scientists and engineers from Western Europe.

We met for the first time in 1994 in Warsaw. Another group of people involved with aircraft design, mainly from Western Europe, met the same year in Madrid and decided to organise the Aircraft Design Workshops. Since then they have met regularly every two years (in Berlin, Bristol, Torino, and Linkoping) and in some sense they act parallel to us. Nobody possesses a monopoly on any aircraft design activity. Maybe we need to establish an agreement with these groups of people and jointly organise a wider forum?

At our last Seminar in Tallinn, participants decided that the next Seminar would be held in Brno in the Czech Republic. Our Ukrainian colleagues expressed their desire to host the Seminar in 2010. We also believe that one of the future Seminars will be held in Moscow.

Table. Seminars in numbers

\begin{tabular}{|c|c|c|c|c|}
\hline Location & Year & $\begin{array}{c}\text { Number of participants / } \\
\text { foreign participants }\end{array}$ & $\begin{array}{c}\text { Number of } \\
\text { presentations }\end{array}$ & $\begin{array}{c}\text { Papers published in Seminar } \\
\text { Proceedings or other journals }\end{array}$ \\
\hline Warsaw & 1994 & $82 / 17$ & 31 & 26 \\
\hline Warsaw & 1996 & $200 / 80$ & 105 & 87 \\
\hline Warsaw & 1998 & $150 / 74$ & 90 & 66 \\
\hline Warsaw & 2000 & $185 / 110$ & 144 & 18 \\
\hline Vilnius & 2002 & $72 / 52$ & 60 & 13 \\
\hline Riga & 2004 & $65 / 39$ & 54 & $?>$ \\
\hline Tallinn & 2006 & $81 / 51$ & 46 & $\Sigma>289$ \\
\hline & & $\Sigma=835 / 423$ & $\Sigma=530$ & \\
\hline
\end{tabular}

The success of the former Seminars inspires us to continue our activity in the future. The philosophy will probably be little changed. The main challenge now is not to organise an international forum for discussion only, but rather to determine how to better integrate central and eastern European aeronautical research and education with that of Western European research and education, acting under the umbrella of the European Commission. That is why we plan to act jointly with EASN II (European Aeronautic Science Network) and together with DGLR (DGLR organised a multinational conference in May 2006 in Berlin devoted to the cooperation of German aeronautical institutions with their counterparts new member states). Our long-term goal is to stimulate cooperation between the west and east of united Europe to create a European research area in aeronautics.

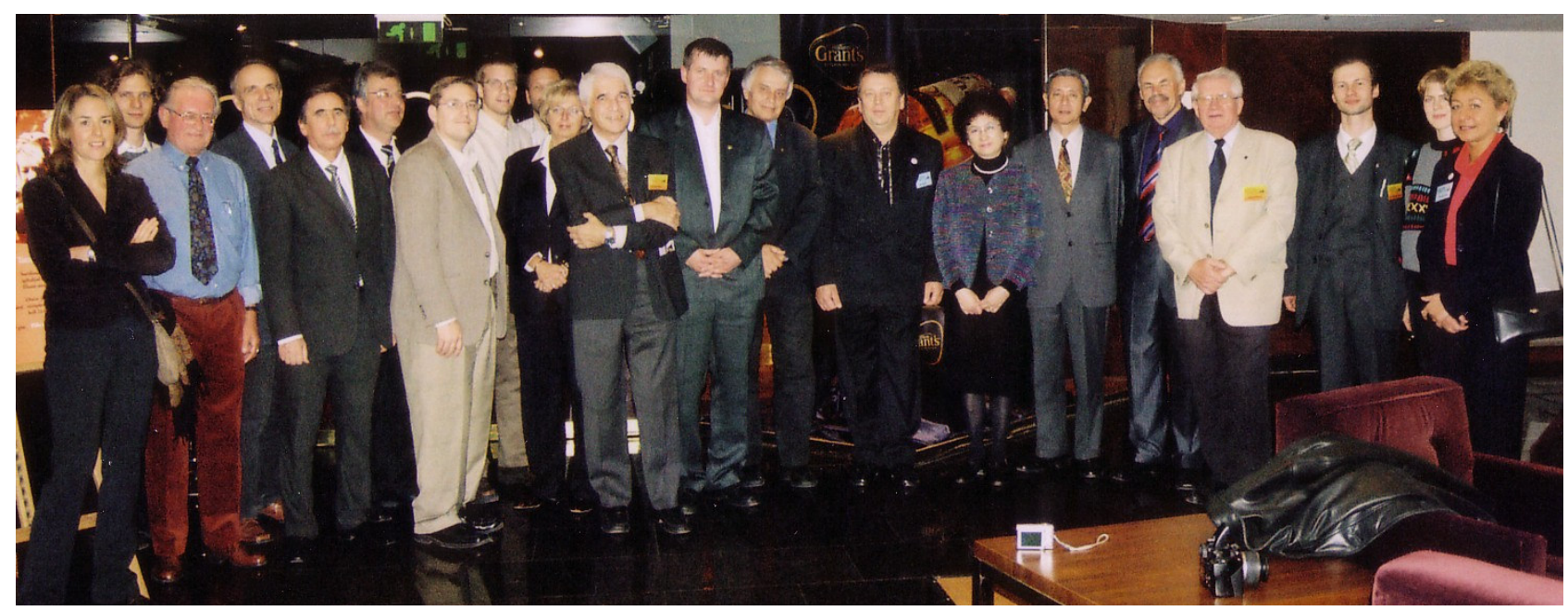

Participants during welcoming reception 


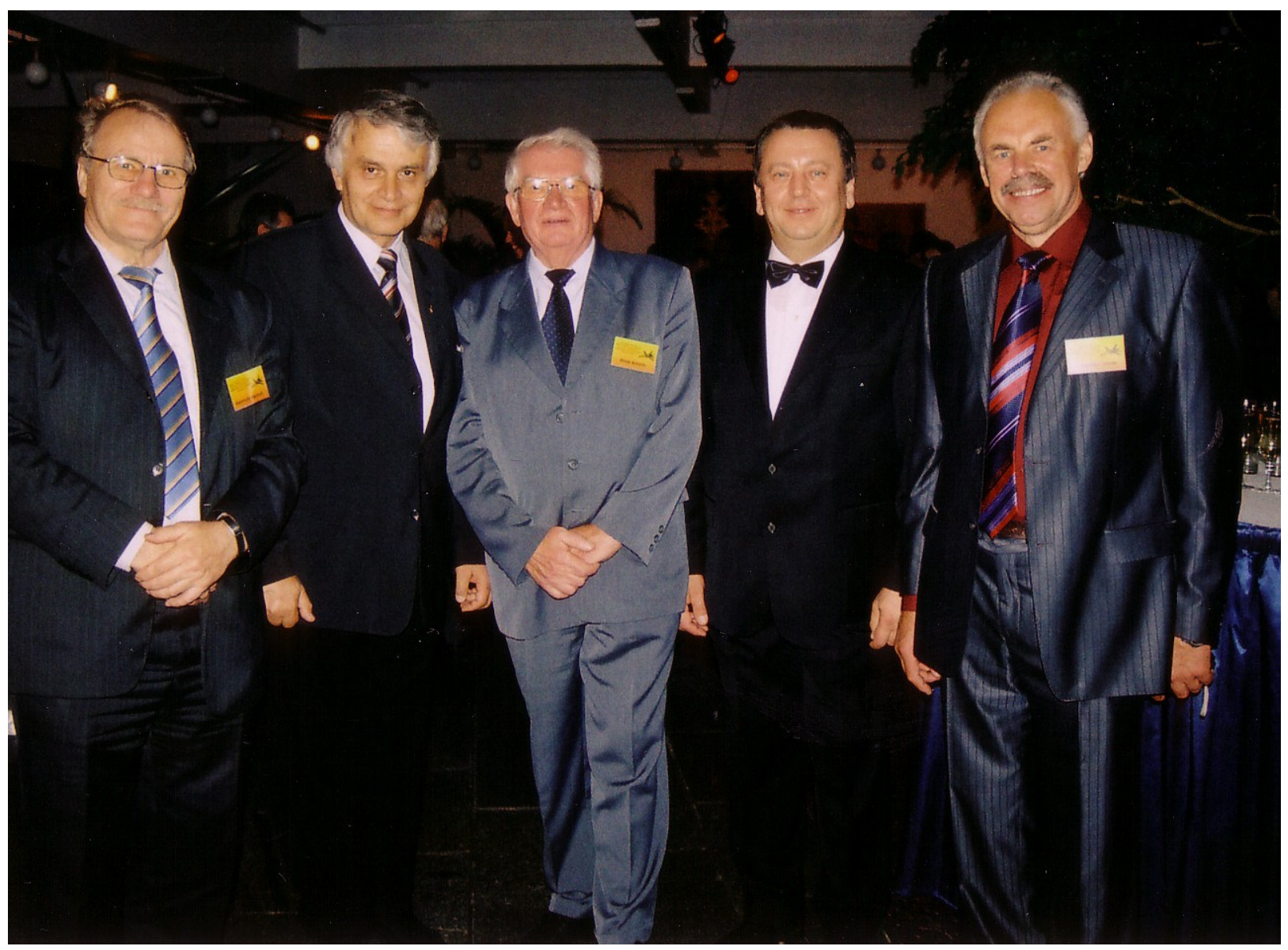

From the left: prof. Martinsh Kleinhofs, prof. Zdobyslaw Goraj, prof. Antonin Pištek, prof. Villu Mikita and prof. Jonas Stankūnas

On behalf the Organizing and Scientific Committee of the RRDPAE Seminar:

prof. Zdobyslaw Goraj - Warsaw University of Technology, Poland, Warsaw prof. Jonas Stankūnas - Gediminas Technical University, Lithuania, Vilnius prof. Martinsh Kleinhofs - Riga Technical University, Latvia, Riga prof. Villu Mikita - Tartu Aviation College, Estonia, Tartu prof. Antonin Pištek - Brno University of Technology, Czech Republic, Brno 